\title{
홍수터여과에서 집수관의 최적설계 연구 A Study on the Optimum Design of Horizontal Collectors in Floodplain Filtration
}

\author{
피성민 · 김승현 ${ }^{\dagger}$ \\ Seong-Min $\mathrm{Pi} \cdot$ Seung-Hyun $\mathrm{Kim}^{\dagger}$ \\ 영남대학교 환경공학과 \\ Department of Environmental Engineering, Yeungnam University
}

(2011년 6월 21일 접수, 2012년 6월 27일 채택)

\begin{abstract}
In order to obtain information on the design parameters of the horizontal laterals in floodplain filtration, laboratoryscale sand-box experiments were performed where the head distributions on the laterals and the groundwater profiles were measured according to the change in parameters including lateral diameter, hydraulic conductivity of the sand, water level at the well and raw-water supply rate. Measured data were analyzed using a numerical code in order to identify the discharge intensity distribution along the laterals. It was observed from the result that the lowering of the water level at the well had minimal adverse effect on the performance of the floodplain filtration. Results also elucidated that the low conveyance of the laterals to transmit the filtrate was compensated and supplemented by a natural augmentation in horizontal conveyance through the aquifer when the raw-water supply rate exceeded the adequate recovery rate. With this mechanism, the water quality is expected to improve further since the travel distance through the aquifer is amplified. Based on these findings it can be suggested that the diameter of the lateral used in the floodplain filtration may be smaller than those in riverbank/bed filtration. It was also found that the ratio between the head loss occurring in a lateral and the total head loss in the floodplain filtration was proportional to the exit velocities of the laterals, which may be used to design and/or evaluate the lateral in floodplain filtration.
\end{abstract}

Key Words : Floodplain Filtration, Recovery System, Laterals, Sand-Box Experiment, Head Distribution

요약 : 홍수터여과에서 집수관의 설계에 대한 자료를 얻기 위해 실험실 규모의 모래통 실험을 수행하였으며, 집수관의 직경, 모래의 투수계수, 집수정의 수위 그리고 지표에서의 원수공급률 등의 변화에 따른 집수관에서의 수두분포와 지하수면 분포를 측정하였다. 측정결과를 수치해석코드에 적용하여 집수관 각 부위에서의 여과수 유입률도 파악하였다. 이들 자료로부터 홍수 터여과에서 집수정의 운영수위를 낮춤으로 인한 부작용은 없을 것으로 예상되었으며, 적절한 회수능력에 비해 원수공급률이 큰 경우 대수층에서의 수평방향의 흐름이 발달하여 수평집수관의 통수능 부족을 보완함을 알 수 있었다. 이 경우 여과수의 토양중 이동거리가 늘어나므로 여과수의 수질개선에도 도움이 될 것으로 판단되었고, 따라서 홍수터여과에서는 강변/하상여 과에서보다 더 작은 직경의 수평집수관을 사용할 수 있음을 알 수 있었다. 전체 수두손실중 수평집수관에서의 수두손실이 차 지하는 비율이 수평집수관 출구유속과 비례함을 알 수 있었으며, 이를 이용하면 홍수터여과에서 수평집수관의 설계와 평가가 가능할 것으로 판단되었다.

주제어 : 홍수터여과, 회수체계, 수평집수관, 모래통실험, 수두분포

\section{1. 서 론}

우리나라는 강우가 짧은 기간에 집중되어 하상계수가 크 며, 홍수에 대비하기 위해 하천에는 넓은 홍수터를 예비하고 있다. 대부분의 홍수터 토양은 투수성이 좋아서 이를 이용하 여 오염된 하천수나 하수처리장 방류수를 토양여과를 통해 정화한 후 하천에 방류하거나 오염된 하천수로부터 깨끗한 상수원수를 얻기 위한 공법으로 홍수터여과가 제안되어 그 가능성이 연구된 바 있다. ${ }^{1 \sim 3)}$ 홍수터여과는 크게 3 부분으로 구성되며, 홍수터 표층에서의 원수공급, 홍수터 토양에서의 연직흐름을 통한 수질정화, 그리고 수평집수관을 이용한 여 과수 회수 등이다.

최 등은 문헌조사를 통해 토양대수층처리 등 홍수터여과 와 유사한 외국기술을 소개하였고, 우리나라의 하천특성에
적당한 홍수터여과 방식을 제안하였다. 또한, 주요 하천의 홍 수터 면적과 각 하천의 몇 개의 지점들에 대해 불포화 투수 계수를 조사하였고 HYDRUS-D)를 이용하여 이들 홍수터 토양의 오염수 처리능력도 산정하였으며, 이 공법의 적용시 하천수질과 상수원수의 수질을 크게 개선시킬 수 있다고 하 였다. 김과 김은 모래통 실험과 낙동강 상류, 중류, 그리고 하류의 대표지점에서의 현장실험을 통해 홍수터 표면에서 의 최적 원수공급체계를 연구하였다. 연구결과 토양환경을 호기상태로 유지하고 표층의 폐색을 방지하며 홍수유실이 나 조류발생 등에 대응하기 위해서는 지표범람에 의해 원수 를 공급하되 이를 간헐적으로 중단하는 방식이 적당하다고 하였다. 이들이 제안한 적당한 범람/휴지의 지속시간은 대 략 30 분/15분이었다. 김과 김 ${ }^{3)}$ 은 홍수터여과를 모사하는 모 래통 실험을 통해 하수처리장 방류수를 처리하였으며, 지표 


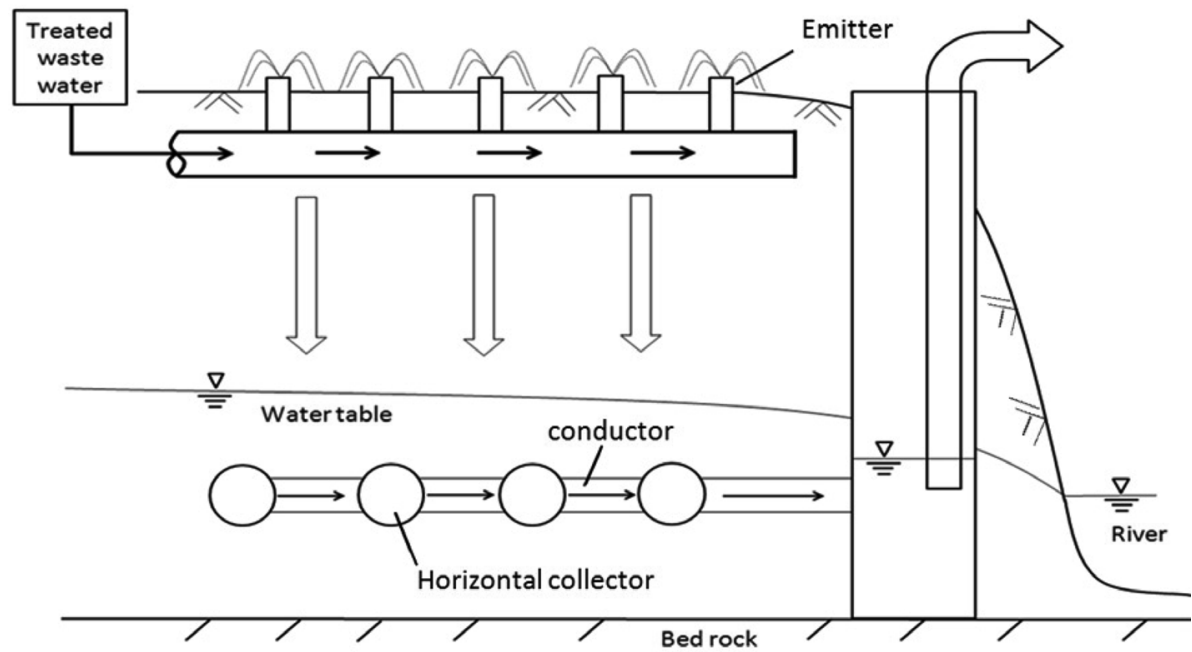

Fig. 1. Schematization of floodplain filtration.

면에서 범람/휴지의 지속시간을 30 분/15분으로 하여 원수를 공급하면서 운전에 따른 폐색 정도와 토양깊이에 따른 용 존산소 및 각종 오염물의 거동을 측정하였다. 실험결과 범 람을 간헐적으로 중단시킴으로써 토양환경이 호기상태로 유 지됨을 확인할 수 있었고, 대부분의 오염물질 제거는 토양 깊이 1 2 m에서 일어남을 알 수 있었다. 또한, 이들은 운전 경과에 따라 표층의 폐색현상이 진행하는 것을 관측하였고, 표층의 폐색을 방지하기 위해서는 주기적으로 1 2일 정도 의 완전건조가 필요하며 그 주기는 토양에 따라 2 4주 정 도임을 알 수 있었다. 이들의 연구로부터 홍수터여과의 가능 성과 적절한 원수공급방식 및 원수공급률 그리고 오염제거 에 필요한 여과깊이를 알 수 있었다.

홍수터여과의 또 다른 구성요소는 정화된 여과수를 회수 하는 것이다. 홍수터여과에서는 오염된 물을 다량으로 홍수 터 표면에 주입하므로 토양내부가 쉽게 혐기화 할 수 있어 서 이를 방지하기 위해서는 토양표면에서 범람/휴지를 반복 적으로 적용하는 원수공급방식이 바람직하다. 이는 토양내의 공기를 대기와 주기적으로 소통시켜 토양환경에서 용존산소 농도를 높이기 위함이며, 토양이 불포화상태일 때 토양내의 여과수에 대한 산소침투가 활발해진다. 불포화토양에서 물 과 공기의 접촉면적은 매우 크기 때문이다. ${ }^{5 \sim 6)}$ 한편, 홍수터 여과와 비슷한 공법으로 미국의 서부나 이스라엘 등지에서 많이 행하고 있는 토양대수층처리(Soil Aquifer Treatment)에 서는 상당히 넓은 함양지 주변에 다수의 수직정을 배치하여 여과수를 회수하는 방식을 적용하고 있어 ${ }^{7,8)}$ 여과수가 연직 방향뿐 아니라 수평방향으로도 상당한 거리를 이동하게 된 다. 이 방식을 우리나라에 적용하는 경우 발생 가능한 문제 는 최 등이 정리하였으며, 함양지 아래의 지하수위가 높아지 고 담수에 의해 함양지 아래의 토양에는 공기가 유통되기 어 려우므로 수평방향으로 긴 여과거리를 이동하는 동안 철, 망 간 등이 용출되거나 심한 경우 황산이온이 환원되어 여과수 의 수질이 상당히 나빠질 우려도 있다. 더욱이 이러한 혐기 환경에서는 토양으로부터 인의 용출이 촉진되므로 자칫 하
천수질에 치명적인 인의 농도를 증가시키는 원천이 될 수도 있다. ${ }^{9}$ 따라서 좁은 면적에서 대량의 수처리가 바람직한 우 리나라의 홍수터여과 방식은 원수공급형태뿐 아니라 여과수 회수체계도 우리나라의 실정에 적합하여야 하며, 불포화영역 이 깊어지도록 지하수위를 낮추고 여과수의 불필요한 수평 흐름을 억제하기 위하여 원수주입영역의 연직하방의 가급적 깊은 곳에 수평집수관을 설치하여 여과수를 회수하는 방식 이 바람직한 것으로 판단된다. 이를 고려한 홍수터여과의 개 요도는 Fig. 1에 나타내었다.

홍수터여과에서 여과수 회수용 수평집수관의 설계는 집수 관의 길이, 직경, 개공률, 그리고 설치간격 등을 목표유량에 적당한 값으로 결정하는 것이다. 이를 위해서는 대수층의 투 수계수와 집수정에서의 수위저하, 그리고 수평우물의 여러 설계요소에 따른 산출유량의 변화를 파악해야 하며, 그 방 법은 수평우물의 수리학에 근거한다. 수평우물의 수리학적 해석은 Hantush와 Papadopulos ${ }^{10)}$ 가 최초로 수행하였으며, 이 들은 강에서 일정한 거리에 위치한 수평우물의 수위저하에 따른 산출유량 계산식을 유도하였다. 그 후 많은 연구자들이 다양한 대수층 및 경계 조건에 대해 수평우물의 산출유량 계 산식을 제시하였다. ${ }^{116)}$ 이들은 수평우물을 선형 싱크(sink) 로 보고 우물전체에 걸쳐 일정수두 또는 일정유입률 경계조 건을 적용하였으며, 수평우물 내부에서의 흐름은 고려하지 않았다.

수평집수관(수평우물)이 긴 경우 집수관(우물) 내부의 축 방향 흐름에 의한 마찰저항은 무시할 수 없으며, 이를 고려 한 최초의 연구는 $\operatorname{Tarshish}^{11)}$ 에 의해 수행되었고 집수관 내 부의 마찰저항에 의해 집수관으로의 유입률은 일정하지 않 게 된다고 하였다. Chen 등 $^{18)}$ 은 대수층과 집수관에서의 흐 름을 통합한 수학적 모델링과 하상여과를 모사하는 모래통 실험을 통해 지금까지 수평우물에 일정수두 또는 일정유입 률 경계조건을 적용한 것은 오류이며, 이는 수평집수관 내부 에서의 마찰저항을 무시하는 것이라고 하였다. Mohamed와 Rushton $^{19)}$ 은 집수관 해석을 위한 흐름영역을 대수층에서 집 
수관으로의 흐름, 집수관을 통과하는 흐름, 집수관 내부에서 의 축방향 흐름의 3 부분으로 나누어서 수학적 모델에 모두 반영하였고, 실규모의 현장실험 측정치를 그들의 수학적 모 델로 해석하였다. 해석결과 수평집수관이 짧은 경우에는 집 수관 전체에 걸쳐 일정유입률 경계조건을 적용하는 것이 가 능하지만 집수관이 긴 경우에는 집수관에서의 위치에 따라 유입률이 달라진다고 하였다.

$\mathrm{Kim}$ 등은 하상여과용 수평집수관 내부에서의 축방향 흐 름을 해석하기 위해 Bernoulli의 원리를 적용한 수학적 모델 을 수립하였고, 집수관 직경과 길이, 우물의 양수율 그리고 모래의 투수계수를 변화시키면서 모래통 실험도 수행하였다. 연구결과 집수관 내부의 흐름은 집수관의 끝에서 집수정으 로 흐르는 동안 여과수가 집수관 벽을 통해 지속적으로 유입 함에 따라 축방향 유량은 점점 더 많아지고 따라서 유속은 점점 더 빨라지며, 유속증가에 따라 압력은 감소하므로 여 과수의 집수관 유입률은 점점 더 커진다고 하였다. 또한, 집 수관에서의 유효수두의 분포형태는 대수층에서의 저항과 집 수관 내부에서의 축방향 흐름에 대한 저항의 균형에 의해 결정되고, 따라서 집수관의 길이, 직경, 모래의 투수계수, 우 물의 산출유량 등에 의해 영향을 받으며, 이들 다양한 변수 들을 망라하는 인자는 집수관 출구에서의 축방향 유속이라 고 하였다. 그들이 제시한 기준치는 $1 \mathrm{~m} / \mathrm{sec}$ 로, 이보다 더 큰 출구유속을 가지는 경우에는 대수층에서의 저항보다 집수 관에서의 축방향 흐름에 대한 마찰저항이 커서 우물효율이 낮게 되고, 이 경우 일정수두로 가정하면 오차가 커진다고 하였다.

집수관에서의 마찰저항으로 인해 집수정에서 먼 지점의 유 효수두가 상승하면 대수층에서 집수관으로 여과수를 유입하 게 하는 수리학적 구동력이 감소하며, 이의 개요도를 Fig. 2 에 나타내었다. 우물을 수변에서 상당한 거리에 설치하는 강 변여과에서 집수관 끝부분의 수두가 상승하면 하천수와 집 수관 사이의 동수경사가 줄어서 집수관의 산출유량이 감소한 다. 홍수터여과와 마찬가지로 여과수가 주로 연직하향으로 흐르는 하상여과의 경우에는 집수관 끝부분의 수두가 상승 하면 집수관의 출구부근 즉, 집수정 부근에서 여과수가 집중 적으로 유입하여 오염제거효율이 감소할 뿐 아니라 수리학 적으로도 비효율적인 우물이 된다. 이러한 현상을 방지하기

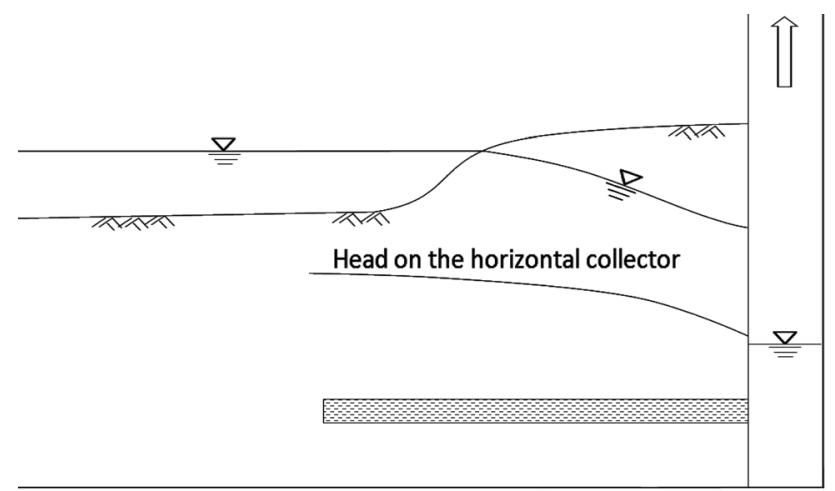

Fig. 2. Hydraulic head distribution on the horizontal lateral.
위해서는 Fig. 2에서 집수관의 수두분포를 평평하게 만드는 것이 중요하며, 이를 위해 직경이 큰 집수관을 사용해야 한 다. ${ }^{20)}$ 한편, 하상여과에서 하천수가 수평으로 자유롭게 이동 하여 집수관의 출구부근에서 집중여과가 가능한 것과는 달 리 홍수터여과의 경우에는 지표에서 원수의 이동이 억제되 므로 원수 함양률이 지점에 따라 다르지 않고 거의 균일하 여 집중여과의 가능성이 크게 줄어든다. 즉, 홍수터여과에서 집수관의 어느 부위에 유입하는 여과수는 그 부위의 연직상 방의 일정면적의 표층부에서 공급되는 유량에 토양중에서 발생하는 수평흐름을 더한 만큼이 된다. 따라서 홍수터여과 에서는 강변/하상여과에 비하여 직경이 더 작은 집수관을 사 용해도 될 것으로 판단되며, 이에 대한 정확한 이해가 필요 하다 할 것이다.

본 연구에서는 홍수터여과를 모사하는 모래통 실험을 수 행하였으며, 집수관의 직경, 모래의 투수계수, 집수정의 수 위, 그리고 지표면에서의 원수공급률 등 여러 요소들을 변화 시키면서 집수관 바깥면에서의 수두와 지하수면의 분포를 측정하였다. 측정결과는 수치해석코드로 해석하여 집수관 각 부위별 여과수 유입률을 파악하였으며, 대수층과 집수관에 서의 수두손실을 해석하여 홍수터여과에서 여과수 회수체계 의 설계에 대한 지침으로 활용될 수 있게 하였다.

\section{2. 실험장치 및 방법}

본 연구에서는 폭 $24 \mathrm{~cm}$, 길이 $200 \mathrm{~cm}$, 높이 $60 \mathrm{~cm}$ 인 모 래통을 실험장치로 사용하였다. 이는 모래통의 내부규격이 며, 두께 $10 \mathrm{~mm}$ 인 폴리카보네이트로 제작하였다. 모래통에 는 수평집수관을 설치하였으며, 사용된 집수관의 내경은 3 종류로 $3.0 \mathrm{~cm}, 2.0 \mathrm{~cm}$, 그리고 $1.0 \mathrm{~cm}$ 이었고, 그 두께는 모 두 $0.7 \mathrm{~mm}$ 인 스텐레스강이었다. 집수관은 바닥에서 $6 \mathrm{~cm}$ 높이에 길이방향으로, 모래통 한쪽 벽면과 $2 \mathrm{~cm}$ 이격하여 모래통 전체길이에 걸쳐 수평으로 설치하였다. 집수관의 개 공률은 최소 $22 \%$ 로 집수관 유입시 발생하는 손실수두는 크 지 않을 것으로 판단되었다. ${ }^{21)}$ 집수관의 바깥면에는 압력수 두 측정을 위해 외경 $3.0 \mathrm{~mm}$, 두께 $0.5 \mathrm{~mm}$ 인 비닐튜브로 만 든 마노미터를 설치하였다. 설치간격은 출구부 $60 \mathrm{~cm}$ 에서는 $10 \mathrm{~cm}$, 나머지 구간에서는 $20 \mathrm{~cm}$ 이었다. 모래통은 $55 \mathrm{~cm}$ 깊 이로 모래를 채웠다. 모래통에 연결하여 집수정을 운영하 였으며, 이는 밑면적이 $10 \times 24 \mathrm{~cm}$ 인 아크릴통을 수직으로 세워 모래통에 부착한 것으로, 바닥으로부터 $15 \mathrm{~cm}, 25 \mathrm{~cm}$, 그리고 $35 \mathrm{~cm}$ 높이에 중심을 가지는 직경 $5 \mathrm{~cm}$ 인 원형의 구멍을 뚫어 여과수의 출구로 사용하였다. 모래통 상부에는 원수를 공급하기 위해 인공강우 발생기를 설치하였다. 이 장 치는 모래통 전체표면적을 $8 \times 8 \mathrm{~cm}$ 의 정 4 각형 격자로 나 누고 각 정4각형의 중앙에 직경 $1 \mathrm{~mm}$ 의 구멍을 뚫어 원수 가 연직하방으로 공급되도록 한 것이었다. 원수공급시 물줄 기에 의해 모래표면이 교란되는 것을 방지하고 공간적으로 균일한 공급이 되도록 모래표면을 두께 약 $2 \mathrm{~mm}$ 의 토목섬 


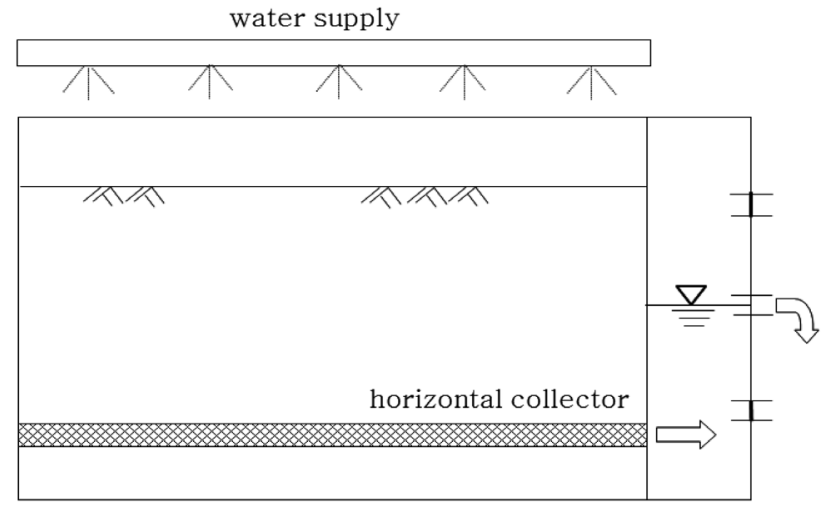

Fig. 3. Schematic diagram of experimental apparatus.

유로 덮었다. 모래통 실험장치의 개요도는 Fig. 3에 나타내었 다. 실험에는 수돗물을 사용하였다. 모래는 두 종류를 사용 하였으며, 투수계수는 각각 $0.289 \mathrm{~cm} / \mathrm{sec}$ 와 $0.116 \mathrm{~cm} / \mathrm{sec}$ 이 었다. 사용된 모래의 투수계수는 지하수면의 측정치와 모델 예측치를 비교하여 결정했으며, 결정방법은 결과 및 고찰에 설명되어 있다.

실험은 모두 4단계로 나누어 수행하였다. 첫 단계에서는 내경 $2 \mathrm{~cm}$ 인 집수관을 설치하고 투수계수가 $0.116 \mathrm{~cm} / \mathrm{sec}$ 인 모래를 채운 후 원수공급률을 $9.4 \mathrm{~m}^{3} / \mathrm{m}^{2}$-day로 유지하였으 며, 집수정의 수위를 $15 \mathrm{~cm}, 25 \mathrm{~cm}$ 그리고 $35 \mathrm{~m}$ 로 조정하면 서 각각의 집수정 수위에 대해 집수관 표면의 수두와 지하 수위 분포를 관측하였다. 관측은 집수정의 수위를 변동하 고 충분한 시간이 경과한 후 정상상태에서 수행하였다. 두번 째 단계에서는 내경 $2 \mathrm{~cm}$ 인 집수관을 설치하고 투수계수가 $0.116 \mathrm{~cm} / \mathrm{sec}$ 인 모래를 채운 후 집수정의 수위를 $15 \mathrm{~cm}$ 로 고정하고, 원수공급률을 $3.5 \mathrm{~m}^{3} / \mathrm{m}^{2}$-day, $9.4 \mathrm{~m}^{3} / \mathrm{m}^{2}$-day 그리 고 $16.7 \mathrm{~m}^{3} / \mathrm{m}^{2}$-day로 변화시키면서 앞의 항목들을 관측하였 다. 이 실험에서도 관측은 원수공급률을 변동하고 충분한 시 간이 경과한 후 정상상태에서 수행하였다.

세번째 단계에서는 집수관의 내경을 $1 \mathrm{~cm}, 2 \mathrm{~cm}$, 그리고 $3 \mathrm{~cm}$ 로 변화시키면서 앞의 항목들을 관측하였다. 이때 모래 의 투수계수는 $0.116 \mathrm{~cm} / \mathrm{sec}$ 이었고, 집수정의 수위는 $15 \mathrm{~cm}$ 이었으며, 적용한 원수공급률은 $9.4 \mathrm{~m}^{3} / \mathrm{m}^{2}$-day이었다. 마지 막으로 네번째 단계의 실험에서는 내경 $2 \mathrm{~cm}$ 인 집수관과 투수계수가 $0.289 \mathrm{~cm} / \mathrm{sec}$ 인 모래를 사용하고 집수정의 수 위는 $15 \mathrm{~cm}$ 를 적용하였으며, 원수공급률은 $9.4 \mathrm{~m}^{3} / \mathrm{m}^{2}$-day을 적용하면서 앞의 항목들을 관측하였다. 여기에서 지하수위 는 집수관 상부의 지하수면을 의미하며, 집수관이 설치된 반 대편 벽면에서의 지하수위도 관측하였다. 실험에서 유량은 매스실린더와 스톱와치로 측정하였고, $20 \pm 1{ }^{\circ} \mathrm{C}$ 로 조절된 실 내에서 실험을 수행하였다.

\section{3. 결과 및 고찰}

모든 실험에서 집수관 상부의 지하수위와 집수관에 평행 한 벽면에서의 지하수위 분포는 거의 같았으며, 가까운 쪽
벽면에서는 그 수위차이가 $1 \mathrm{~mm}$ 이하이고 반대쪽 벽면의 지 하수위와도 그 차이가 최대 $3 \mathrm{~mm}$ 에 불과하였다. 따라서 모 래통 내부에서 집수관에 직각방향의 물 흐름은 무시하였다. 첫번째 실험에서 얻은 집수정의 수위에 따른 집수관에서의 수두분포와 지하수위분포를 각각 Fig. 4(a)와 (b)에 나타내 었다. 집수정에서의 수위변화에 따른 분포형태의 변화는 거 의 없음을 알 수 있다. 집수관에서의 수두분포는 모든 경우 에 출구방향으로 갈수록 낮아지는데 이는 집수관에서의 물 흐름 특성에 의한 것이다. $\mathrm{Kim}^{20)}$ 등에 의하면 집수관 전체길 이에 걸쳐서 여과수가 유입하므로 집수관의 출구쪽으로 갈

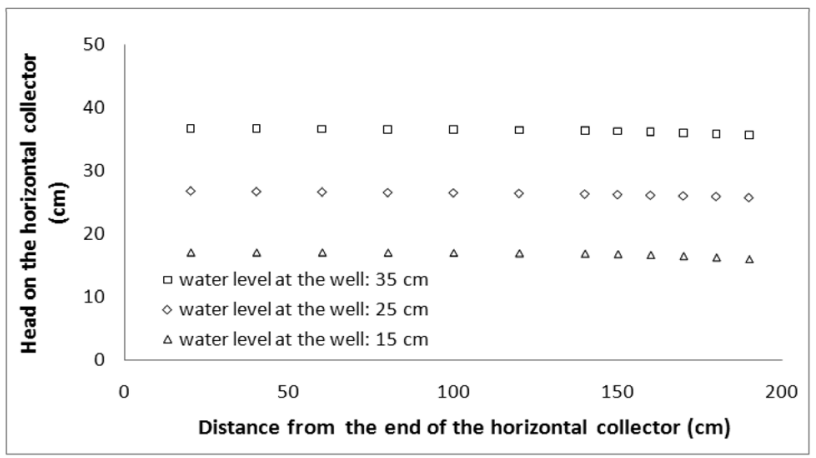

Fig. 4(a). Distribution of the head on the horizontal collector according to the water level at the well (hydraulic conductivity : $0.116 \mathrm{~cm} / \mathrm{sec}$, collector diameter : $2 \mathrm{~cm}$, rawwater supply rate: $9.4 \mathrm{~m}^{3} / \mathrm{m}^{2}$-day).

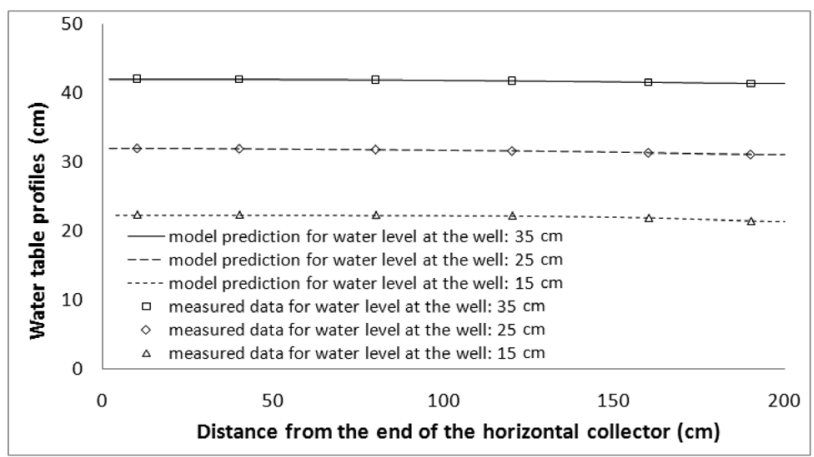

Fig. 4(b). Water table profiles according to the water level at the well (the same condition as above).

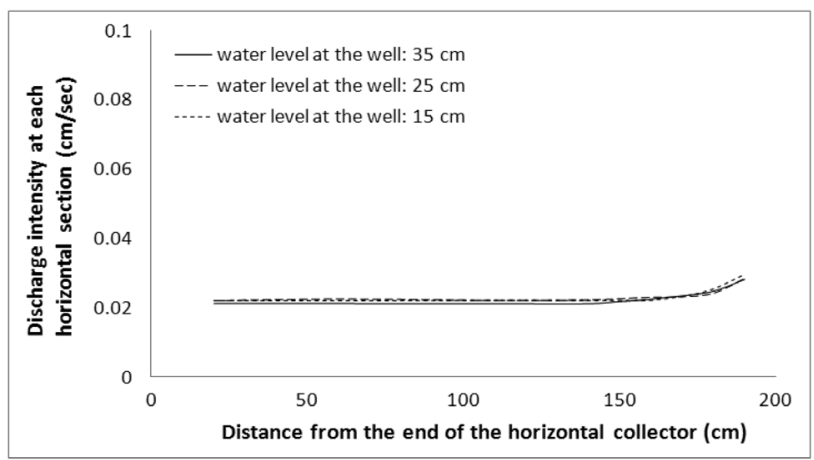

Fig. 4(c). Discharge intensity distribution along the horizontal collector according to the water level at the well (the same condition as above). 
수록 집수관 내부에서의 축방향 유량과 유속은 점차 증가하 고 이로 인해 압력은 점차 감소하며, 이에 따라 여과수 유입 률은 점차 커진다고 하였다. 이를 다른 관점에서 보면, 집수 관에서의 축방향 흐름에 대한 마찰저항에 의해 집수정에서 의 수위저하가 집수관 전체길이에 그대로 전달되지 못하여, 집수정에서 멀어질수록 집수관에서의 수두가 점점 더 높아 진다는 것이다. 일반적으로 난류흐름에서 마찰저항은 유속 의 제곱에 비례하므로 출구에 가까이 갈수록 집수관의 수두 감소가 급격해지는데 Fig. 4(a)에서는 이들이 완만히 감소하 며, 이는 집수관에서의 축방향 유속 즉, 산출유량이 크지 않 기 때문이다. 한편, Fig. 4(b)에서 지하수위도 모든 경우에 출 구쪽으로 갈수록 완만하게 낮아지는데 이는 출구로 갈수록 집수관으로의 여과수 배출이 잘되어 지하수위가 낮아지고 따라서 집수정에서 먼 쪽의 지하수가 모래층에서의 흐름을 통하여 출구쪽으로 수평이동하여 이를 보충하는 현상이라 할 수 있다.

Fig. 4(a)와 (b)의 측정값을 이용하여 집수관 각 부위에서 의 여과수 유입률을 계산하였다. 계산에는 MODFLOW ${ }^{22}$ 를 이용하였고, 그 결과는 Fig. 4(c)에 나타내었다. 계산방법은 함양률(또는 원수공급률)과 집수관 각 부위에서의 수두 측 정치를 MODFLOW에 대입하고, 모래의 투수계수를 여러 값 으로 변화시키면서 MODFLOW를 이용한 지하수위 예측치를 얻어 이를 실측치와 비교하였다. 이들 두 값을 가장 잘 부합 시키는 투수계수 값은 $0.116 \mathrm{~cm} / \mathrm{sec}$ 이었고, 이때 MODFLOW 를 이용한 지하수위 예측치를 실측치와 비교하여 Fig. 4(b) 에 실선으로 나타내었으며 이들이 잘 일치함을 알 수 있다. MODFLOW적용시 영역은 모래통의 규격을 그대로 사용하 였고, 블록의 길이 $\times$ 폭 $\times$ 높이는 $2 \times 3 \times 4 \mathrm{~cm}$ 로 하였다. 집수 정에서의 수위가 달라도 Fig. 4(a)와 (b)에서와 마찬가지로 여과수 유입률 분포는 같은 양상을 보이고 있으며, 여과수 유입률은 집수관 전체길이에 걸쳐 거의 일정하다가 출구부근 에서 다소 증가함을 알 수 있었다. Kim 등에 의하면 여러 요 소들의 영향으로 인해 정도의 차이는 있지만 이는 수평우물 이 가지는 일반적인 특성이다. 한편, 집수관의 어떤 지점에서 여과수 유입률은 그 지점에서의 지하수위와 집수관의 수두 와의 차이에 비례하는데 Fig. 4의 (a)와 (b)의 차이보다 (c) 가 출구부근에서 더 큰 것을 알 수 있으며, 이는 모래층 내 부에서 상당한 양의 지하수가 수평으로 흐름을 나타내고 있 다. 실규모의 홍수터여과 운영에서는 처리대상수의 수질이 나쁜 경우 더 깊은 호기대가 필요므로 집수정의 수위를 낮추 어 이를 얻게 되며, Fig.4에서 알 수 있듯이 집수정의 수위를 낮춤으로 인해 발생하는 부작용은 없는 것으로 판단되었다.

두번째 실험결과인 원수공급률의 변화에 따른 집수관의 수 두분포와 지하수위분포를 각각 Fig. 5(a)와 (b)에 나타내었다. 원수공급률이 4 배 이상으로 크게 변했음에도 불구하고 집수 관의 수두분포는 거의 같은 형태를 유지하고 있었으며, 수두 값들도 원수공급률에 따라 크게 다르지는 않았다. 실규모의 홍수터여과에서 원수공급률은 대략 $5 \mathrm{~m}^{3} / \mathrm{m}^{2}$-day 이하로 예 상되므로(김과 김, 2010) 본 실험에서와 같은 조건으로 설계

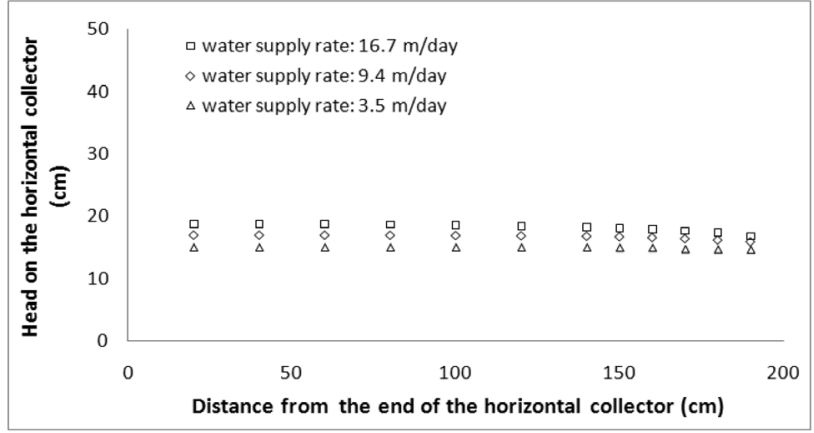

Fig. 5(a). Distribution of the head on the horizontal collector according to the raw-water supply rate (hydraulic conductivity: $0.116 \mathrm{~cm} / \mathrm{sec}$, collector diameter: $2 \mathrm{~cm}$, water level at the well : $15 \mathrm{~cm}$ ).

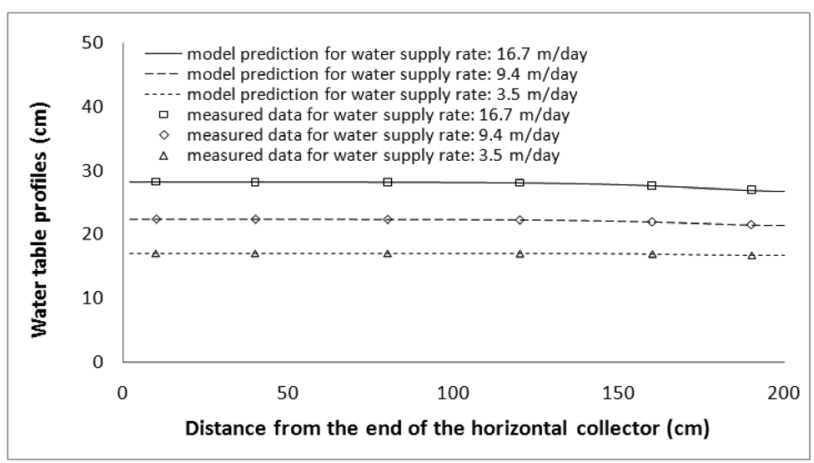

Fig. 5(b). Water table profiles according to the raw-water supply rate (the same condition as above).

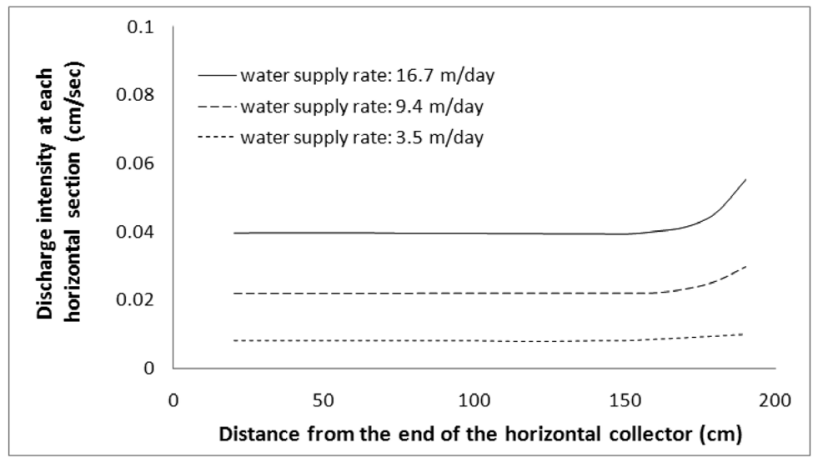

Fig. 5(c). Discharge intensity distribution along the horizontal collector according to the raw-water supply rate (the same condition as above).

및 운영된다면 실규모에서도 출구부근에서 집수관의 수두분 포곡선이 크게 왜곡되는 경우는 발생하지 않을 것으로 예상 되었다. Fig. 5(b)에서도 Fig. 4(b)에서와 마찬가지로 출구로 갈수록 지하수면이 낮아지는 것을 알 수 있으며, 원수공급률 이 클수록 출구부근에서의 수면곡선왜곡이 커져서 모래층 내부에서 지하수의 출구방향 수평흐름이 증가하는 것을 알 수 있었다. 이는 하상여과와는 다른 기작이며, 하상여과에서 는 대수층에서 여과수의 출구방향 수평흐름이 거의 없는데 비해 홍수터여과에서는 집수관에서의 흐름뿐 아니라 대수층 에서도 출구방향의 흐름이 발생하므로 더 작은 직경의 집수 
관을 사용할 수 있으며, 이 기작은 원수공급률이 클수록 더 활성화한다는 것을 알 수 있었다. 집수관 각 부위에서의 여 과수 유입률을 앞에서와 같은 방법으로 구하여 Fig. 5(c)에 나타내었다. Fig. 4(c)에서와 대략 같은 형태를 보이고 있으나 집수관 전체의 여과수 유입률은 원수공급률에 따라 크게 차 이가 나고 있으며, 특히 출구부근에서의 유입률 급증현상이 원수공급률 증가에 따라 심화되고 있음을 알 수 있었다.

세번째 실험결과인 집수관의 직경변화에 따른 집수관의 수두분포와 지하수위분포를 각각 Fig. 6(a)와 (b)에 나타내

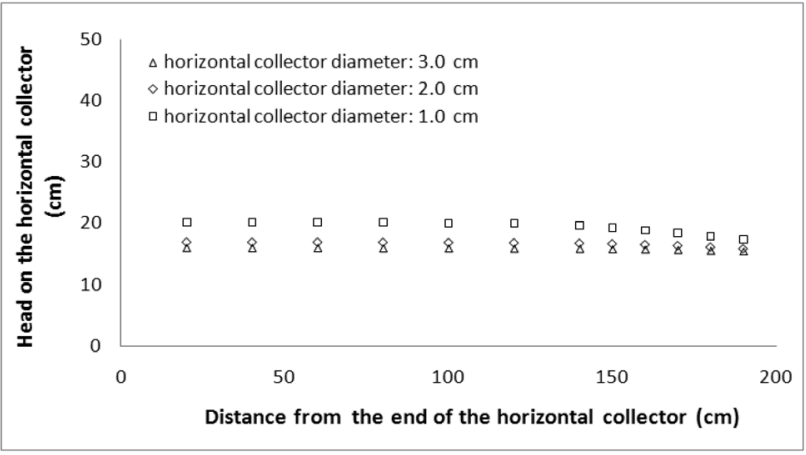

Fig. 6(a). Distribution of the head on the horizontal collector according to the collector diameter (hydraulic conductivity: $0.116 \mathrm{~cm} / \mathrm{sec}$, collector diameter: $2 \mathrm{~cm}$, water level at the collector well : $2 \mathrm{~cm}$, raw-water supply rate : $9.4 \mathrm{~m}^{3} / \mathrm{m}^{2}$-day).

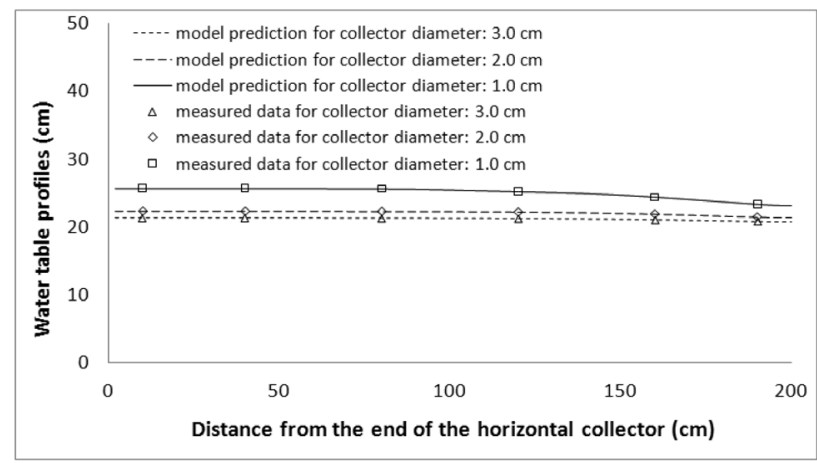

Fig. 6(b). Water table profiles according to the collector diameter (the same condition as above).

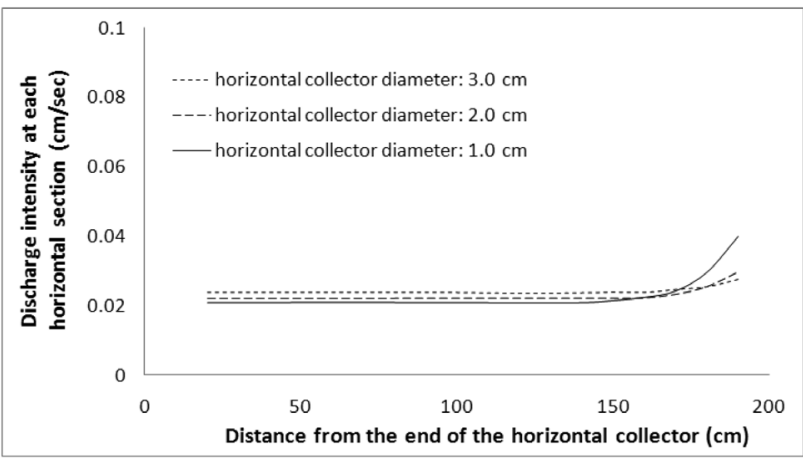

Fig. 6(c). Discharge intensity distribution along the collector according to the horizontal collector diameter (the same condition as above).
었다. 직경이 $3 \mathrm{~cm}$ 인 경우에는 집수관에서의 수두분포가 수 평에 가까워 우물효율이 높음을 알 수 있었다. 그러나 모든 경우에 출구로 갈수록 수두분포곡선이 더 왜곡되어 여과수 유속증가와 이로 인한 마찰증가 및 수두손실증가로 우물효 율은 감소함을 알 수 있었다. 또한, 이 경향은 직경이 작을수 록 심화됨을 알 수 있었다. 그러나 직경이 작은 경우에는 출 구부근에서 지하수위분포도 더 왜곡되므로 Fig. 5에서와 같 이 모래층 내부에서 지하수의 수평이동이 가능하여 홍수터 여과에서 우물효율의 감소를 완화시킴을 알 수 있었다. 각 경 우에 대해 집수관 각 부위에서의 여과수 유입률을 앞에서와 같은 방법으로 해석하여 Fig. 6(c)에 나타내었으며, 집수관의 산출률은 원수공급률과 같으므로 서로 같지만 직경이 작을 수록 출구부근에서의 유입이 더 커짐을 알 수 있었다. 이로 부터 홍수터여과에서는 하상여과에서와 같은 큰 직경의 집 수관을 사용할 필요가 없음을 알 수 있다. 작은 직경을 사용 하면 집수관을 통한 여과수 배수에 더하여 대수층에서의 흐 름도 발생하여 작은 직경으로 인한 집수관의 통수능 저하를 보완해주는 기작이 자동으로 형성되기 때문이다. 한편, 집수 관의 직경이 작은 경우 포화대수층에서의 수평방향 이동거 리가 증가하여 여과수의 수질개선효과는 더 좋아질 것으로 판단되었다.

마지막으로 네번째 실험결과인 투수계수 변화에 따른 집 수관의 수두분포와 지하수위분포를 각각 Fig. 7(a)와 (b)에 나 타내었다. 집수관의 수두분포는 가는 모래의 경우 그 왜곡도 가 좀 더 심했으나 굵은 모래의 투수계수가 가는 모래의 2 배 이상인 점을 고려하면 그 차이가 크지는 않았다. 이는 동일 한 직경의 집수관과 동일한 원수공급률을 적용했음에도 불 구하고 여과수가 집수관 전체길이를 통해 흐르면서 발생하 는 수두손실이 가는 모래의 경우에 더 크다는 의미이다. 이 현상은 하상여과와는 대조적이며, 하상여과에서는 투수계수 가 작은 경우 수평집수관에서의 수두손실이 더 작았다고 한 다. ${ }^{20)}$ 지하수위분포는 투수계수가 작은 경우에 더 높게 형 성되었고, 지하수위와 집수관 수두 사이의 차이 즉, 모래층 통과시 발생하는 수두손실은 투수계수가 작은 경우에 더 컸다. 이는 Darcy의 법칙에 의하면 당연하며, 동일한 원수 공급률을 적용하여 흐름률이 같은 경우 투수계수가 작은 쪽의 저항이 더 크기 때문이다. Hill과 Zhu는 유전개발분야 에서 이러한 특성을 이용하여 집유관 즉, 수평우물에서의 저항과 유전(또는 대수층)에서의 저항의 상대적 크기를 비 교함으로써 수평우물의 효능을 평가할 수 있다고 하였으며, Fig. 7에서 투수계수가 작은 경우 집수관에서의 수두손실은 투수계수가 큰 경우에 비해 다소 크지만 대수층에서의 수두 손실에 비교한 상대적인 비율은 더 작아서 이때의 상대적 우 물효능은 더 좋다고 평가한다. MODFLOW를 이용하여 집 수관 각 부위에서의 여과수 유입률을 앞에서와 같은 방법으 로 해석하여 Fig.7(c)에 나타내었으며, 이로부터 계산한 굵 은 모래의 투수계수는 $0.289 \mathrm{~cm} / \mathrm{sec}$ 이었다. Fig. 7(c)에서 투 수계수가 작은 경우 수평우물의 상대적 효율이 더 좋음에도 불구하고 출구부근에서의 여과수 집중유입이 더 심한 것은 


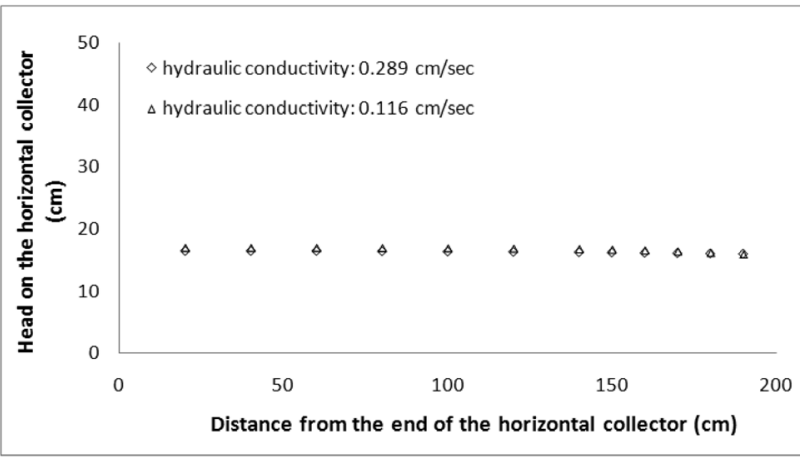

Fig. 7(a). Distribution of the head on the horizontal collector according to the hydraulic conductivity of the sand (lateral diameter : $2 \mathrm{~cm}$, water level at the collector well : $15 \mathrm{~cm}$, raw-water supply rate: $9.4 \mathrm{~m}^{3} / \mathrm{m}^{2}$-day).

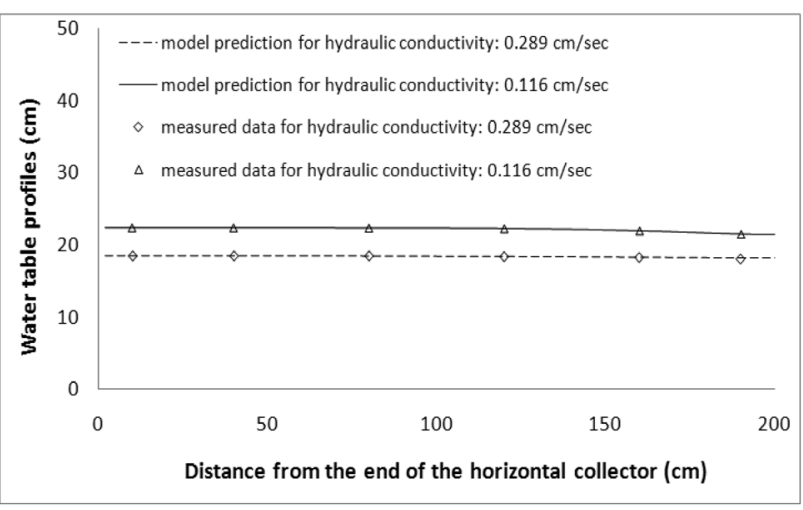

Fig. 7(b). Water table profiles according to the hydraulic conductivity of the sand (the same condition as above).

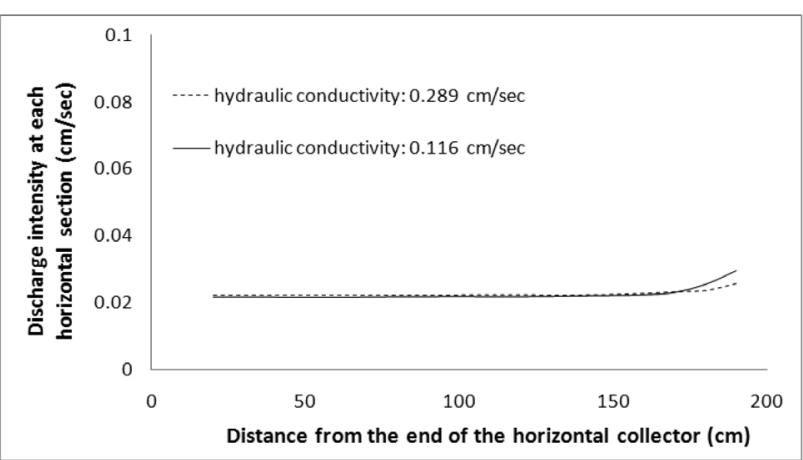

Fig. 7(c). Discharge intensity distribution along the horizontal collector according to hydraulic conductivity of the sand (the same condition as above).

유전개발이나 하상여과에서와는 달리 본 연구의 경우 모래 층에서의 수평흐름이 상당하였기 때문으로 판단되었다. 이와 같은 기작은 집수관에서의 수두분포와 지하수면의 형상이 출구부근에서 더 많이 왜곡되는 현상과 더불어 발생하고 있 으며, Fig. 5와 6에서도 알 수 있듯이 원수공급률에 비해 여 과수 회수능력이 상대적으로 더 작은 경우에 공통적으로 발 생하는 현상이었다.

홍수터여과에서 수평집수관의 최적설계를 도출하기 위하 여 여러 가지 인자들을 변화시키면서 실험을 수행하고 그 결
과를 해석하여 각 인자들이 수평집수관과 홍수터여과의 효 능에 어떻게 영향을 주는지 고찰하였다. 홍수터여과의 설계 와 평가에서 이와 같이 여러 인자들의 영향을 각각 고려하는 것도 필요하지만 이들 여러 인자들을 망라하는 하나의 대표 인자를 파악하여 활용하는 것도 가능하다면 도움이 될 수 있 을 것이다. 홍수터여과와 유사한 하상여과에서는 설계에 매 우 중요한 인자인 수평집수관의 길이와 직경 그리고 대수층 의 투수계수 등과 밀접한 관계를 가지면서 이들 모두를 망 라하는 인자가 수평집수관에서의 출구유속이라 하며, 이 유 속이 $1 \mathrm{~m} / \mathrm{sec}$ 를 넘는 경우에는 수평집수관에서의 수두손실 이 대수층에서의 수두손실에 비해 상대적으로 너무 커서 수 평집수관의 효능이 좋지 않게 된다고 하였다. 홍수터여과의 설계와 해석을 위해서 본 연구에서는 Hill과 Zhu가 제안한 우물효능 평가방법을 적용하였으며, 수행된 모든 실험자료 (미발표 자료 포함)를 이용하여 수평집수관과 포화대수층에 서 발생하는 수두손실의 합 즉, 전체 수두손실중에서 수평 집수관에서의 손실이 차지하는 비율을 수평집수관 출구유 속의 함수로 보아 Fig. 8에 나타내었다. 여기서 수평집수관 과 대수층에서의 수두손실(m)은 각각 $h_{L C}$ 와 $h_{L A}$ 로 나타내 었다. $h_{L C}$ 는 수평집수관 양끝에서의 수두차이고, $h_{L A}$ 는 수평 집수관 출구에서 가장 먼 지점에서의 지하수위와 수평집수 관에서의 수두와의 차이를 나타낸다. 수평집수관에서의 수 두손실이 전체 수두손실에서 차지하는 비율은 출구유속과 선형으로 비례함을 알 수 있으며, 출구유속이 약 $0.7 \mathrm{~m} / \mathrm{sec}$ 이상인 경우에는 수평집수관에서 발생하는 수두손실이 대 수층에서의 손실보다 더 커서 비효율적인 수평집수관임을 알 수 있었다. 그러나 이 경우에도 하상여과와 달리 홍수터 여과에서는 포화대수층을 통한 여과수의 수평흐름이 상당 하여 수평집수관의 통수능을 보완하는 기작이 작용하고, 이 로 인해 여과수질은 더욱 좋아지므로 이를 고려하여 하상/ 강변여과에 비해 다소 작은 직경의 수평집수관을 사용하는 것도 가능할 것으로 판단되었다. 또한, 수평집수관에서의 수 두손실과 출구유속을 알면 Fig. 8로부터 대수층에서의 수두 손실 즉, 수평집수관 끝부분에서의 지하수위상승 높이를 알 수 있으므로 홍수터여과의 설계와 평가에 활용될 수 있을 것이다.

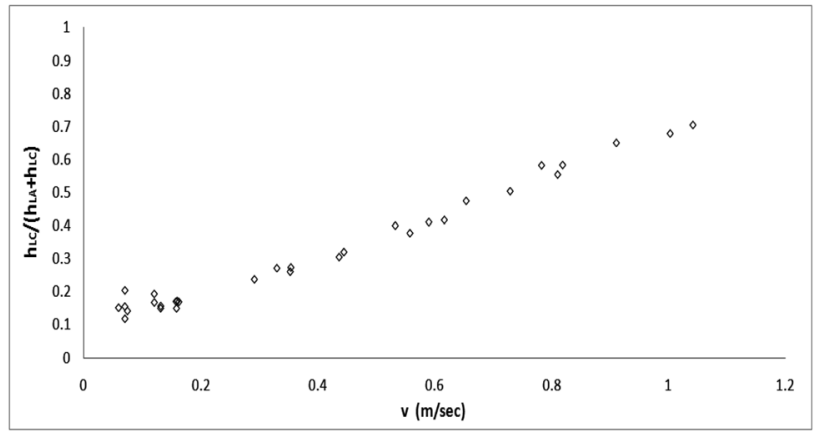

Fig. 8. The ratio between well bore pressure drop and total pressure drop as a function of exit velocity of horizontal collector. 


\section{4. 결 론}

홍수터여과에서 집수정의 운영수위를 것으로 예상되었다. 수평집수관의 직경이 작거나 토양의 투수계수가 작아서 여 과수 회수능력에 비해 원수공급률이 큰 경우 대수층에서의 수평방향의 흐름이 발달하여 수평집수관의 통수능 부족을 일부 보완함을 알 수 있었다. 이 경우 집수관 출구부근에서 여과수 유입률이 증가하고 여과수의 토양중 이동거리가 늘 어나므로 여과수의 수질개선에 도움이 될 것으로 판단되었 고, 따라서 홍수터여과에서는 강변/하상여과에서보다 더 작 은 직경의 수평집수관을 사용할 수 있음을 알 수 있었다. 또 한, 전체 수두손실중 수평집수관에서의 수두손실이 차지하는 비율이 수평집수관 출구유속과 비례함을 알 수 있었으며, 이 를 이용하면 홍수터여과에서 수평집수관의 설계와 평가가 가 능할 것으로 판단되었다.

\section{사 사}

본 연구는 환경부 Eco-STAR Project(수생태복원 사업단)의 연구비 지원으로 수행되었으며 이에 감사의 뜻을 표합니다.

KSEE

\section{참고문헌}

1. 최명호, 김경수, 김승현, "우리나라에서 홍수터여과의 가능 성에 대한 기초조사,” 대한환경공학회지, 31(1), 70 78(2009).

2. 김호석, 김승현, "홍수터여과에서 원수공급체계의 설계요 소에 대한 실험연구," 대한환경공학회지, 31(11), 957 964 (2009).

3. 김호석, 김승현, "홍수터여과에서 원수공급방식에 따른 폐 색현상 및 수질개선도 연구,” 대한환경공학회지, 33(2), 120 131 (2011).

4. Simunek, J., Sejna, M., Saito, H., Sakai, M. and van Genuchten, M. Th., "The HYDRUS-1D Software Package for Simulating the One-Dimensional Movement of Water, Heat and Multiple Solutes in Variably Saturated Media," Department of Environ mental Sciences, University of California at Riverside, California, U.S.A.(2008).

5. Kim, S. H., Lee, Y. D. and Ro, H. M., "Partitioning of butachlor at air-water interface and transport in unsaturated sandy soils," Environ. Eng. Sci., 18(2), 115 123(2001).

6. Cary, J. W., "Estimating the surface area of fluid phase interfaces in porous media," J. Contam. Hydrol., 15, 243 248 (1994).
7. Kanarek, A. and Michail, M., Groundwater recharge with municipal effluent: DAN region reclamation project, Israel, Water Sci. Technol., 34, 227 233 (1996)

8. Bouwer, H., Rice, R. C., Lance, J. C. and Gilbert, R. G., "Rapid-infiltration research at Flushing Meadows Project, Arizona," J. WPCF, 52(10), 2457 2470 (1980).

9. Ponnamperuma, F. N., "The chemistry of sub merged soils," Adv. Agronomy, 24, 29 96(1972).

10. Hantush, M. S. and Papadopulos, I. S., "Flow of ground water to collector wells," Proc. Am. Soc. Civil Engrs. 88, HY, 221 244(1962).

11. Cleveland, T. G., "Recovery performance for vertical and horizontal wells using semianalytical simulation," Ground Water, 32, 103 107(1994).

12. Zhan, H., "Analytical study of capture time to a horizontal well," J. Hydrol., 217, 46 54(1999).

13. Zhan, H. and Cao, J., "Analytical and semi-analytical solution of horizontal well capture times under no-flow and constant-head boundaries," Adv. Water Res., 23(8), 835 848 (2000).

14. Zhan, H., Wang, L. V., and Park, E., "On the horizontal-well pumping tests in anisotropic confined aquifers," J. Hydrol., 252, 37 50(2001).

15. Park, E. and Zhan, H., "Hydraulics of horizontal wells in fractured shallow aquifer systems," J. Hydrol., 281, 147 158 (2003).

16. Zhan, H. and Park. E.,"Horizontal well hydraulics in leaky aquifers," J. Hydrol., 281, 129 146(2003).

17. Tarshish, M., "Combined mathematical model of flow in an aquifer-horizontal well system," Ground Water, 30(6), 931 935(1992).

18. Chen, C., Wan, J. and Zhan, H., "Theoretical and experimental studies of coupled seepage-pipe flow to a horizontal well," J. Hydrol., 281, 159 171(2003).

19. Mohamed, A. and Rushton, K., "Horizontal wells in shallow aquifers: Field experiment and numerical model," J. of $\mathrm{Hy}$ drol., 329, 98 109(2006).

20. Kim, S. H., Ahn, K. H. and Ray, C., "Distribution of discharge intensity along s mall-diameter collector well laterals in a model riverbed filtration," $J$. of Irrigation and Drainage Eng., ASCE, 493 500(2008).

21. Water and Power Resources Service, "Ground Water Manual," 2nd Ed., U.S. Department of the Interior, U.S. Government Printing Office, Denver(1981).

22. Harbaugh, A. W. and McDonald, M. G., "User's documentation for MODFLOW-96. An update to the U.S. Geological Survey Modular Finite-Difference Ground-Water Flow Model," Open File Report 96-485, U.S. Geological Survey, Reston, Virginia, U.S.A.(1996) 